\title{
Ultrastructural Changes in A-Cells Exposed to Diabetic Hyperglycaemia. Observations Made on Pancreas of Chinese Hamsters.*
}

\author{
L. Oroi, W. Stauffacher, W. E. Dulin, A.E. Renold and Ch. Rouiller
}

Institut d'Histologie et d'Embryologie, Institut de Biochimie clinique, and Department of Medicine of the University of Geneva, Switzerland, and Metabolic Diseases Research Unit, The Upjohn Company, Kalamazoo, Michigan, USA

Summary. Pancreatic A-cells of chinese hamsters with diabetes of varying severity and duration were examined by electron microscopy. Two predominant changes were observed: 1. Lysosomal digestion of secretory granules ("granulolysis", "crinophagy") occurred in practically all A-cells of diabetic animals but was rarely observed in those of normoglycemic controls. This is considered a response of A-cells to the cessation of glucagon release secondary to hyperglycemia. 2 . In relatively degranulated A-cells of ketotic diabetic animals, dilatation of the cisternae of the RER was seen together with accumulation of pale, flocculent material, possibly reflecting persisting or enhanced glucagon synthesis. In addition, numerous maturing secretory granules were seen in the cisternae of the Golgi complex. Since these apparently contradictory phenomena may be seen in the same cell, it is suggested that "granulolysis" may not only result from decreased hormone release secondary to hyperglycemia but that different and independent stimulatory signals may exist for glucagon synthesis, for glucagon release, and for the initiation of "granulolysis".

Modifications de l'ultrastructure des cellules $A$ dans l'hyperglycémie diabétique. Etudes sur le pancréas du hamster chinois

Résumé. Les cellules A du pancréas endocrine de hamsters chinois atteints d'un diabète de degré et durée variables ont été examinées en microscopie électronique. Deux modifications prédominantes ont été observées: 1. La digestion lysosomiale des granules de sécrétion ("granulolyse» ou (crinophagien) survient dans pratiquement toutes les cellules A d'animaux diabétiques. Par contre, elle n'est que rarement observée chez les animaux témoins non-diabétiques. Ce phénomène est interprêté comme étant une réponse des cellules A à l'arrêt de la libération du glucagon secondaire à l'hyperglycémie. 2. Dans les cellules A relativement dégranulées d'animaux présentant un diabète cétosique, une dilatation des cisternes du réticulum endoplasmique granulaire est observée avec accumulation d'un matériel pâle et flocconneux reflétant probablement une synthèse persistante ou augmentée du. glucagon. En outre, de nombreux granules de sécrétion en. état de formation ont été observées dans les cisternes du complexe de Golgi. Puisque ces deux phénomènes, apparemment contradictoires, peuvent se produire dans une même cellule, il se pourrait que la "granulolyse" résulte non seulement d'une libération diminuée de glucagon faisant suite à l'hyperglycémie, mais qu'il soit en outre nécessaire de faire intervenir des signaux indépendants de la synthèse du glucagon, de sa libération et de l'initiation de la «granulolyse».

Elektronenmikroskopische Veränderungen der A-Zellen bei diabetischer Hyperglykaemie. Untersuchung am Pankreas des chinesischen Hamsters

Zusammenfassung. Flektronenmikroskopische Untersuchungen der A-Zellen des Pankreas diabetischer chinesischer Hamster ließen vor allem zwei Veränderungen erkennen: 1. In praktisch allen A-Zellen diabetischer Tiere konnte der Abbau von $\alpha$-Granula in den von Lysosomen abgeleiteten Strukturen beobachtet werden (,Granulolyse", „Krinophagie"). Dieses Phaenomen wird als Reaktion der Zelle auf eine Verminderung der Glucagonsekretion angesichts anhaltender Hyperglykaemie aufgefaßt. 2. Eine Erweiterung der Cisternae des granulierten ergastoplastischen Reticulums durch eine Anhäufung flockigen, wenig dichten Materials war in A-Zellen ketotisch diabetischer Tiere zu sehen. Diese Beobachtung wird im Sinne einer anhaltenden oder gesteigerten Glucagonsynthese gedeutet. Da beide scheinbar gegensätzlichen Phänomene innerhalb der gleichen Zelle vorkommen, muß die Möglichkeit betrachtet werden, daß die Granulolyse nicht nur das Resultat einer durch Hyperglykaemie bedingten Verminderung der GlucagonSekretion zu sein braucht. Vielmehr ist es wahrscheinlich, daß verschiedene Regulationsmechanismen die Synthese des Glucagons, dessen Sekretion, sowie den Prozeß der "Granulolyse" unabhängig voneinander zu beeinflussen vermögen. Dabei mag der Konzentration des zirkulierenden Glucagons besondere Bedeutung zukommen.

Key-words: Chinese hamster, spontaneous diabetes, Cricetulus griseus, pancreas, islets of Langerhans, A-cells, lysosomes, " $\alpha$-granulolysis", glucagon, glucagon and diabetes, ultrastructure, electron microscopy.
Morphological studies of the endocrine pancreas of normal and diabetic chinese hamsters have been performed in several laboratories, and have permitted the definition of the structural alterations of B-cells characterizing that form of spontaneous diabetes in animals which may most resemble juvenile-onset diabetes of man $[15,13,3,16]$. Much less attention has thus far been focused on the morphology of the A-cells of these animals $[3,16]$.

In the course of experiments concerning the meta-

* Supported in part by the Fonds national suisse de la Recherche scientifique (Grants. No. 4848.3 and 3.154.69). bolic and morphological changes associated with the spontaneously occurring diabetic state of spiny mice and that induced in rats by the injection of streptozotocin, we have repeatedly observed structural alterations suggestive of lysosomal destruction of secretory granules in A-cells of diabetic animals, a process for which the term "alpha-granulolysis" was proposed $[21,20]$. "Granulolysis" or "crinophagy" has been observed in other endocrine cells $[23,5,9]$, and is now considered the morphological expression of an intracellular regulatory response to a shut-down or a slowdown of hormone secretion $[21,20,8]$. 
Table 1. Characterization of chinese hamsters used in the morphological studies

\begin{tabular}{|c|c|c|c|c|c|c|c|c|}
\hline $\begin{array}{l}\text { Animal } \\
\mathrm{No}^{\mathrm{a}}\end{array}$ & $\begin{array}{l}\text { Colony } \\
\text { No }\end{array}$ & & $\begin{array}{l}\text { Age at } \\
\text { death } \\
\text { (months) }\end{array}$ & Clinical assessment $b$ & $\begin{array}{l}\text { Duration of } \\
\text { diabetes } \\
\text { (months) }\end{array}$ & $\begin{array}{l}\text { Plasma } \\
\text { glucose } \\
\mathrm{mg} / 100 \mathrm{ml}\end{array}$ & $\begin{array}{l}\text { Plasma } \\
\text { IRIc }^{\mathrm{c}} \\
\mu \mathbf{U} / \mathrm{ml}\end{array}$ & $\begin{array}{l}\text { Pancreas } \\
\text { IRI } \\
\mathrm{mU} / \mathrm{mg}\end{array}$ \\
\hline 1 & XI - & $2 \pi$ & $22 \mathrm{~m}$ & Mild ketosis, severe at death & $4 \mathrm{~m}$ & 333 & 10 & 0.28 \\
\hline 2 & U9 - & $5 \overline{3}^{2}$ & $3 \mathrm{~m}$ & Control & - & 106 & 78 & 2.7 \\
\hline 3 & AAI - & 70 & $13 \mathrm{~m}$ & Control & - & 110 & 55 & 1.3 \\
\hline 6 & $\mathrm{Z} 2 \quad-$ & $400^{x}$ & $19 \mathrm{~m}$ & Mild, non ketotic & $4 \mathrm{~m}$ & 307 & 213 & 0.54 \\
\hline 7 & W2 - & $22 \hat{O}^{\pi}$ & $13 \mathrm{~m}$ & Severe, non ketotic & $5 \mathrm{~m}$ & 449 & 45 & 0.35 \\
\hline 8 & AFI - & $1{ }^{\star}$ & $6 \mathrm{~m}$ & $\begin{array}{l}\text { Severe, non ketotic } \\
\text { No glycosuria at death }\end{array}$ & $4 \mathrm{~m}$ & 198 & no plasma & 1.46 \\
\hline 9 & $\mathrm{PG}_{9}-$ & $9 \AA$ & $3 \mathrm{~m}$ & Severe ketosis & $2 \mathrm{~m}$ & 442 & $\begin{array}{l}\text { not mea- } \\
\text { surable }\end{array}$ & 0.13 \\
\hline
\end{tabular}

a Missing numbers represented animals which died during transport or were found dead in their cage and could not be studied.

$\mathrm{b}$ Based on assessments of glycosuria (Tes-Tape) and ketonuria (Acetest) in the Upjohn Colony and during the $24 \mathrm{~h}$ preceding death.

c Measurements made at death.



Fig. 1. Normal chinese hamster (animal 3, Table). Part of an A-cell containing numerous secretory granules (sg). The profiles of the rough endoplasmic reticulum may be seen (arrows). Ly $\Rightarrow$ lysosomes, $\mathrm{m}=$ mitochondrion,

$\mathrm{C}=$ capillary, $\mathrm{RBC}=$ red blood cell $(17000 \times)$

Since granulolysis has thus far not been described in A-cells of diabetic chinese hamsters, the present study, using animals with diabetes of varying severity and duration was undertaken.

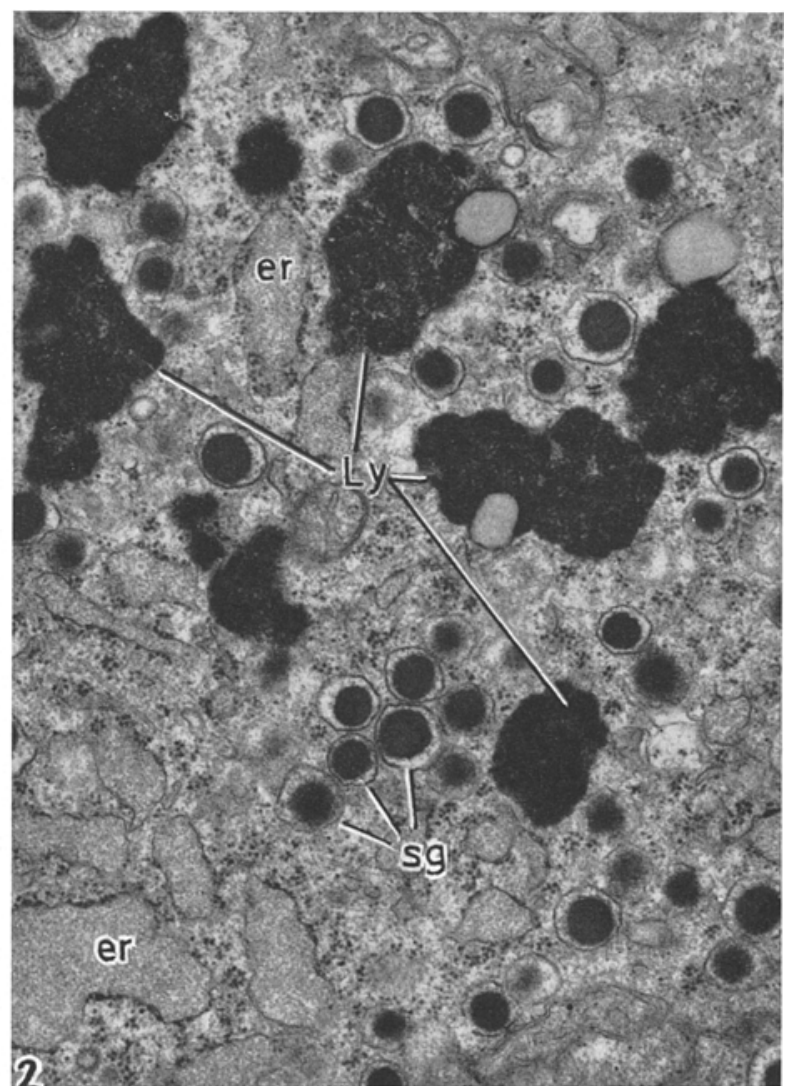

Fig. 2. Severely ketotic chinese hamster (animal 1, Table). The cytoplasm of the A-cell contains numerous lysosomes (Ly). The cisternae of the RER (er) show varying degrees of dilatation and contain pale flocculent material. $\mathrm{sg}=$ secretory granules $(20000 \times)$

\section{Materials and Methods}

7 male chinese hamsters, between 3 and 22 months old, were obtained from the Upjohn Company, Kala- 
mazoo, Michigan, USA. Table 1 summarizes data concerning their age and metabolic state. They were killed by a blow to the head and immediate decapitation; blood for the measurement of plasma glucose and immunoreactive insulin (IRI) was obtained from the neck. The pancreases were immediately dissected free of fat; part of the tissue was used for the extraction and measurement of IRI. Plasma glucose, plasma and pancreatic IRI were measured according to the procedures described elsewhere in this issue [24].

For electron microscopy, small blocks of pancreatic tissue were immediately removed, fixed in phosphate- since they only serve to establish the metabolic state underlying the morphological observations to be reported.

Electron microscopic studies: Fig. 1 shows an example of a normal A-cell with typical electron-dense secretory granules. The rough endoplasmic reticulum (RER) consists of relatively few cisternae. Structures exhibiting the morphological features characteristic for lytic bodies or lysosomes (dense bodies and multivesicular bodies) may be seen. Only rarely do they contain material with texture and electron-density indistinguishable from those of secretory granules.

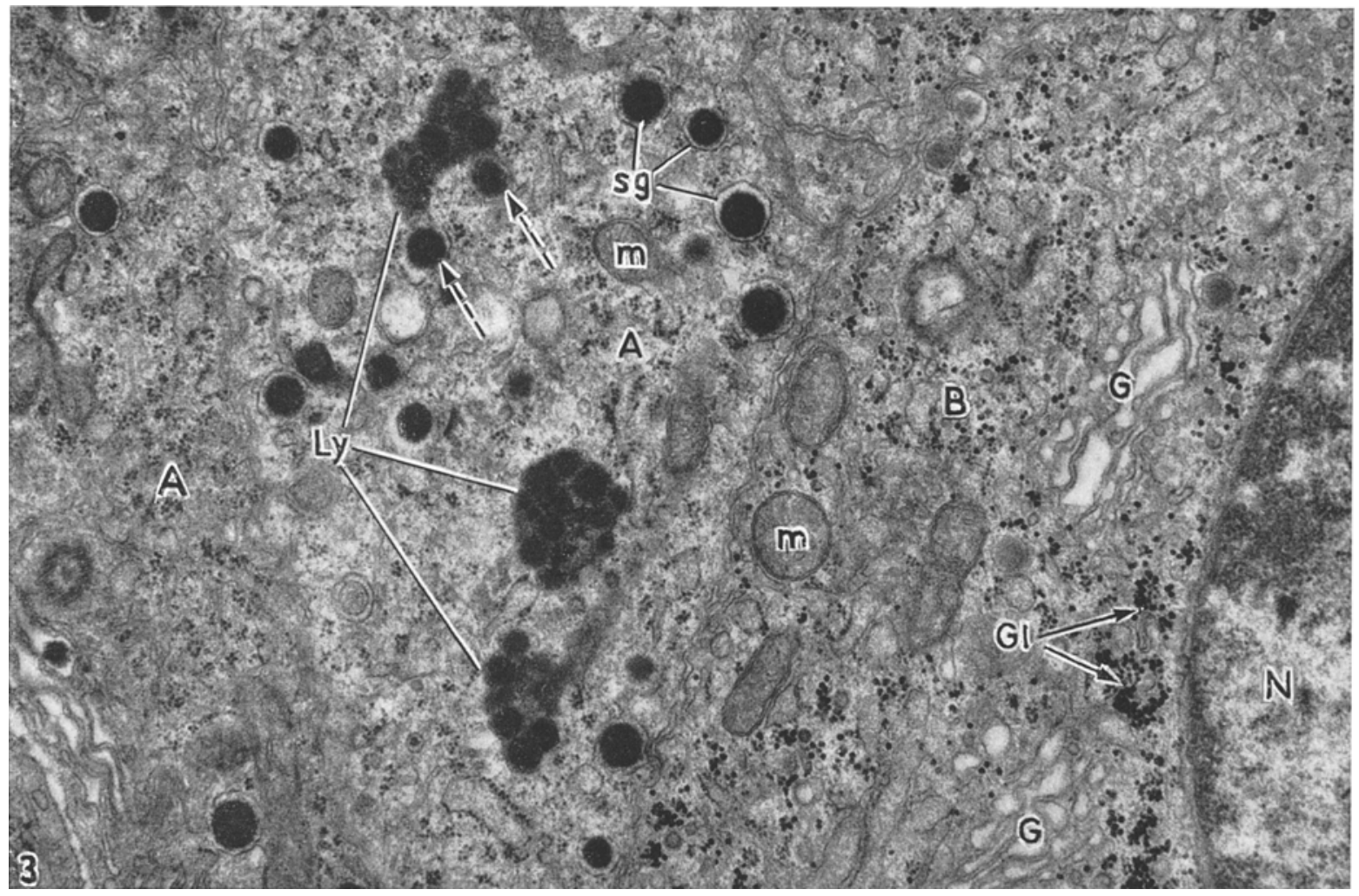

Fig. 3. Mildly diabetic, non-ketotic chinese hamster (animal 6, Table). Part of an A-cell (A) containing few secretory granules (sg) and 3 dense bodies (Ly) which include structures indistinguishable from secretory granules. Arrows indicate 2 secretory granules in close contact with a multigranulated body. $\mathrm{B}=\mathrm{B}$-cell, $\mathrm{m}=$ mitochondrion, $\mathrm{G}=\mathrm{Golg} \mathrm{i}$ complex, Gl = Glycogen, $\mathrm{N}=$ Nucleus $(19000 \times)$

buffered $4 \%$ glutaraldehyde, postfixed in $2 \%$ Osmium tetroxide [17], dehydrated and embedded in Epon [12]. Semi-thin sections were cut with Porter-Blum microtomes in order to identify the islets of Langerhans, and contiguous thin sections were cut with the LKBultramicrotome, stained with lead hydroxide [11] and studied with Zeiss-EM 9 and Philips-300 electron microscopes.

\section{Results}

The biological data (Table 1) confirm those previously reported from other laboratories for similar animals $[22,10,14]$ and will not be commented upon,
While some A-cells of diabetic animals may preserve a normal aspect, a majority shows characteristic alterations in that increasing numbers of lysosomes are found (Fig. 2). Many of the lysosomes contain material resembling the secretory granules (Fig. 3 ). The number of secretory granules to be observed in any one lysosome may vary. For lysosomes containing more than one secretory granule, the term "multigranulated lytic body" has been suggested. In some cells, these multigranulated lytic bodies are particularly numerous (Fig. 4).

Some favorable sections have allowed the identification of structures considered to represent stages of 


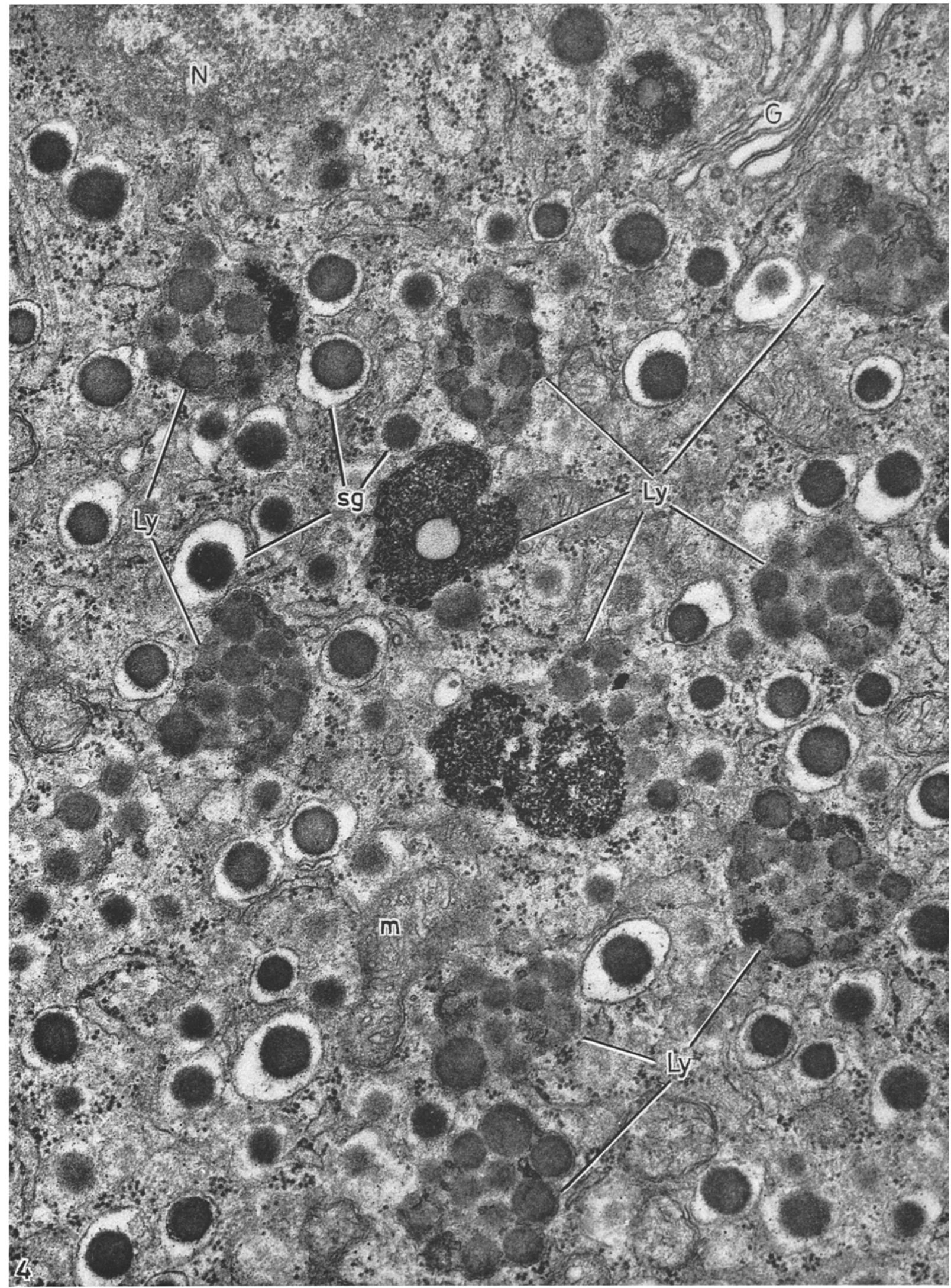

Fig. 4. Mildly diabetic, non-ketotic chinese hamster (animal 6, Table). A-cell containing numerous multigranulated lytic bodies $(\mathrm{Ly})$. The $\alpha$-granules (sg) show an unusually large halo between the dense core and the limiting membrane. $\mathrm{G}=$ Golgi complex, $\mathrm{m}=$ mitochondrion, $\mathrm{N}=$ nucleus $(32500 \times)$ 
as yet hypothetical sequences"which may lead to the formation of lytic bodies containing secretory"granules $[21,20]$. Firstly, secretory granules may be incorporated into pre-existing lysosomes or multivesicular bodies, a process initiated by the juxtaposition of the two structures and the subsequent fusion of their limiting membranes (Figs. 3, 5, 6, 7). Secondly, several secretory granules may fuse with each other so as to form
Apart from granulolysis, accumulation of pale flocculent material in the dilated cisternae of the RER was the most striking alteration to be observed in Acells of ketotic diabetic animals (Figs. 2, 12, 13, 14). In the cells showing this modification of the RER, the number of secretory granules was usually reduced; however, the Golgi complex contained numerous maturing secretory granules (Fig. 13).
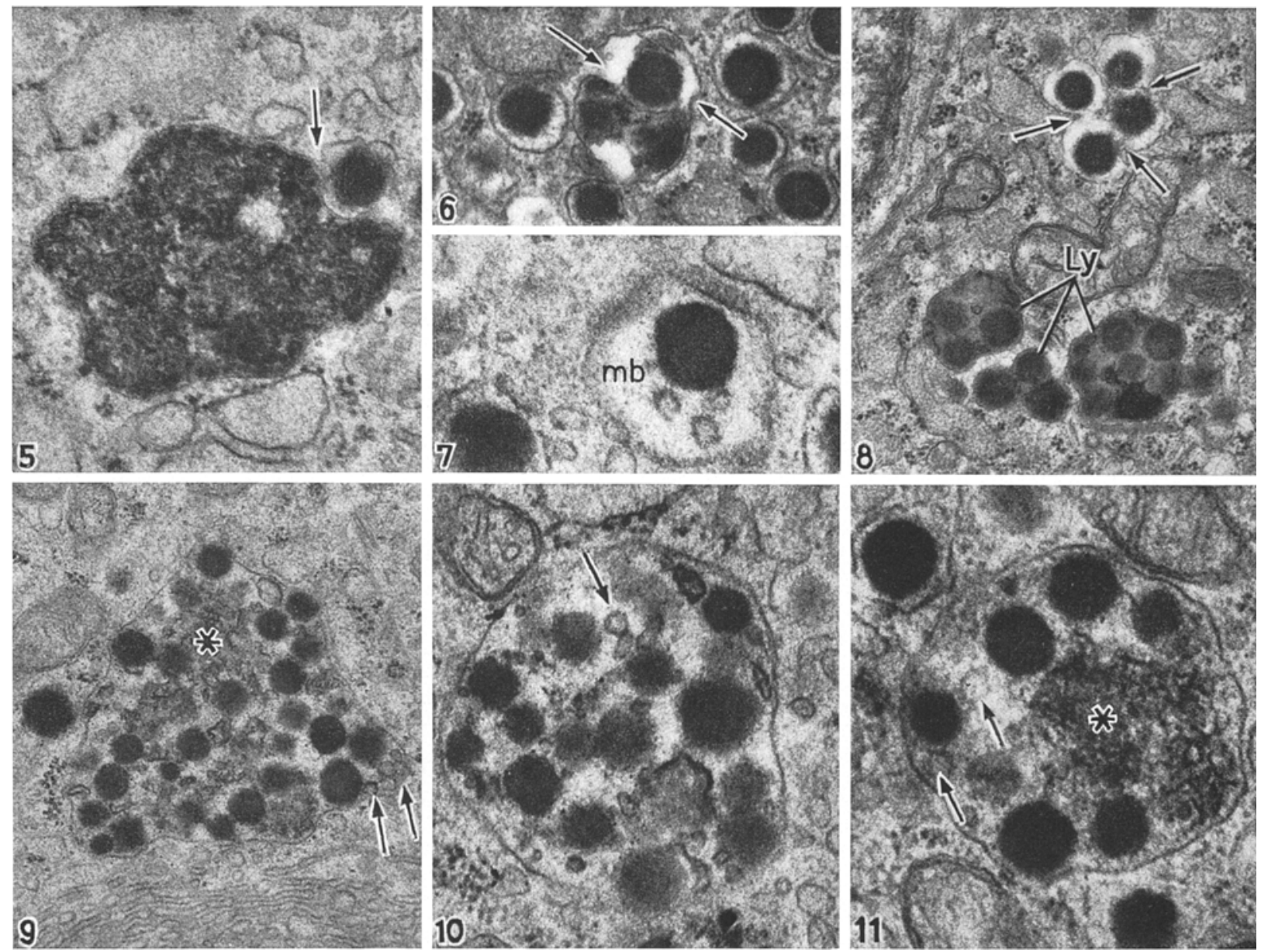

Figs. 5 and 6. Severely diabetic, non-ketotic chinese hamster (animal 7, Table). Hypothetical sequence of the formation of granule-containing lysosomes by fusion of limiting membranes (arrows) and subsequent incorporation of the secretory granules into the lysosome (Fig.5: $49000 \times$; Fig. $6: 25000 \times$ )

Fig. 7. Same animal as Figs. 5 and 6. A multivesicular body $(\mathrm{mb})$ containing a secretory granule $(49800 \times)$

Fig. 8. Non-ketotic diabetic chinese hamster (animal 8,

Table). In the upper part of the picture, a group of 4 closely associated $\alpha$-granules in the process of fusing with each other. This fusion leads to the formation of multigranulated bodies (Ly) as those shown in the lower part of the picture $(22800 \times)$

Figs. 9-11. Same animal as Fig. 8. Multigranulated bodies which, in addition to secretory granules showing varying degrees of degradation, contain microvesicles (arrows) and apparently non-organized residual material (*). (Fig. 9 : $25000 \times$; Fig. 10:43000 $\times$; Fig. 11:51000 $\times$ )

multigranulated bodies, consisting of several granular cores surrounded by a single limiting membrane (Figs. 8 -11). Subsequently, microvesicles, presumably carrying lytic enzymes, may be incorporated into the multigranulated bodies and initiate the process of "granulolysis".

\section{Discussion}

Observations made on spontaneously diabetic spiny mice and on rats rendered diabetic by the injection of streptozotocin have previously led us to suggest that A-cells of the endocrine pancreas might be capable of 
disposing of secretory granules by lysosomal digestion or "alpha-granulolysis" [21,20]. Since glucagon is considered a hormone of glucose need and since acutely induced hyperglycemia appears to reduce its release from the pancreas $[25,28,18,4]$, chronic hyperglycemia may well interfere with the secretory function of the A-cells of diabetic animals. It seemed logical therefore to consider $\alpha$-granulolysis as a hyperglycemianduced mechanism for the destruction of unneeded

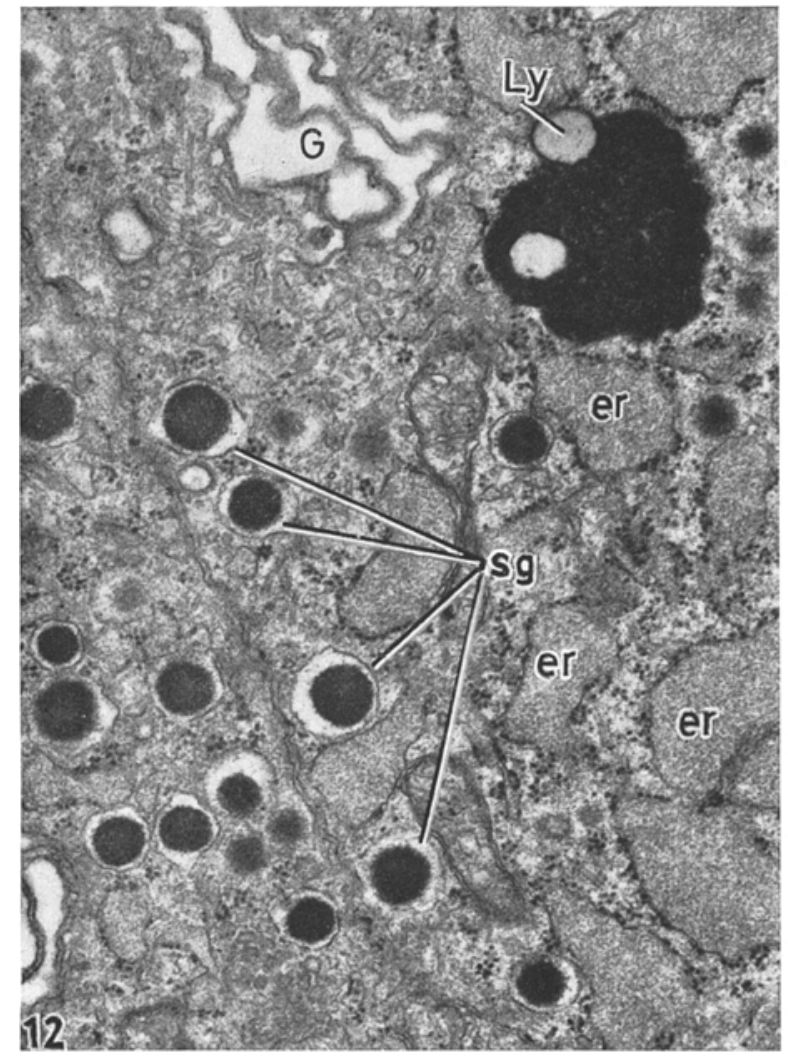

Fig. 12. Severely ketotic chinese hamster (animal 9, Table). Parts of two A-cells. The cisternae of the rough endoplasmic reticulum (er) of the cell on the right hand side are dilated and contain pale flocculent material. Only a few secretory granules (sg) are present in the cytoplasm; they are principally located near the plasma membrane. $\mathrm{G}=$ Golgi complex; $\mathrm{Ly}=$ lysosome $(21.600 \times)$

glucagon [21, 20], and its occurrence in diabetic chinese hamsters is in agreement with this contention. An analogous process had previously been described in prolactin-producing cells of the anterior pituitary gland of lactating rats after the removal of the suckling young; [23] and "granulolysis" or "crinophagy" is now considered the morphological expression of the response of cells producing peptide hormones to the cessation of requirement for the hormone(s) they produce $[21,20$, $23,5,9,8]$.

It is more difficult to account for the other A-cell changes which we have thus far observed only in ke- totic diabetic animals, i.e. the dilatation of the cisternae of the RER by accumulating pale, amorphous material. Similar findings have previously been described by others [16] but thus far no attempt has been made to relate them to the functional state of the A-cell in the metabolic environment of the diabetic organism. Although hyperglycemia would be expected to decrease the release of glucagon and its synthesis, the accumulation of large amounts of material within the cisternae of

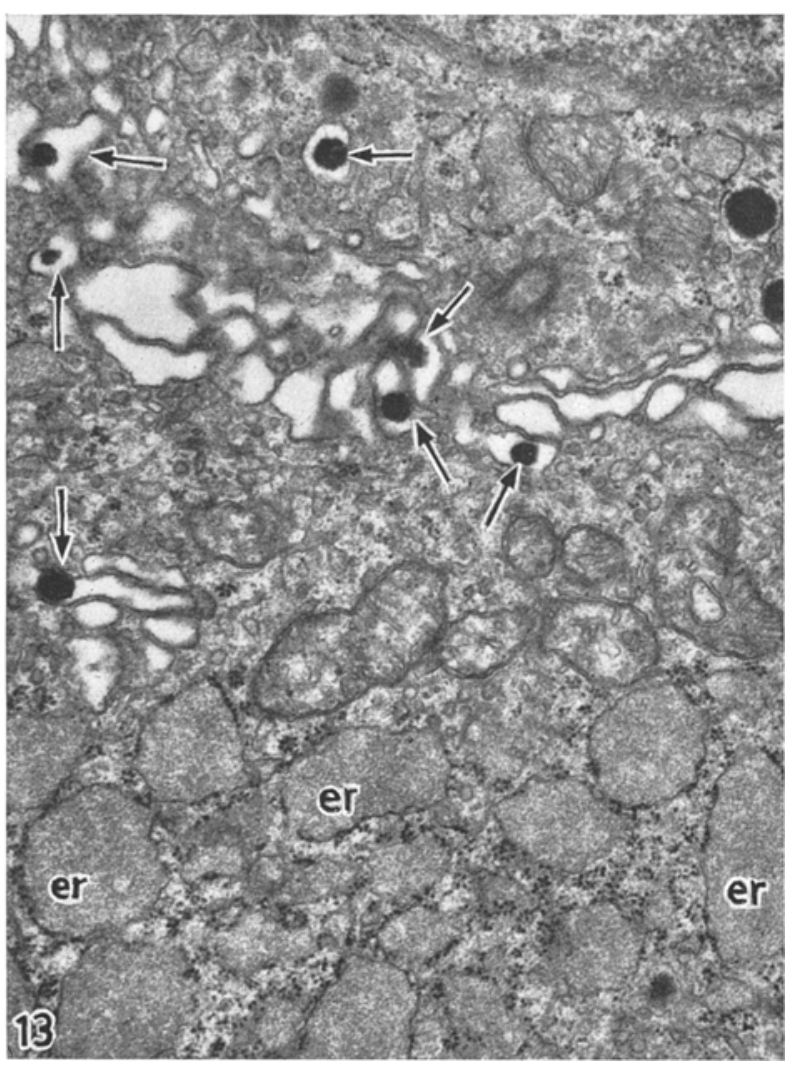

Fig. 13, Severely ketotic chinese hamster (animal 1, Table). The rough endoplasmic reticulum (er) of this A-cell displays similar aspect as that shown in Fig. 12. Numerous maturing secretory granules are seen in the Golgi cisternae (arrows). $(18000 \times)$ the RER suggests that under the conditions prevailing in diabetic ketoacidosis, the rate of glucagon synthesis exceeds that of its storage. In addition, the observation of concomitant relative degranulation of the same Acell indicates that not only the synthesis but also the release of glucagon may be increased. This interpretation seems reasonable in the light of the recent finding of increased levels of circulating glucagon in diabetic ketosis [1]. Although this observation still requires more ample confirmation, it is conceivable that the stimulus for such apparently paradoxical and excessive glucagon secretion might be provided by increased 
levels of amino acids $[2,19,27]$ known to be associated with the diabetic state, by enhanced secretion of enteric hormones such as pancreozymin $[7,26,6]$ consequent to diabetic hyperphagia or, possibly, by a combination of these mechanisms [6]. Finally, the possibility may be considered that the A-cell may itself be insulin-sensitive and require the presence of insulin for the recognition of hyperglycemia with resulting suppression of glucagon release.

Since $\alpha$-granulolysis and the accumulation of pale material with subsequent dilatation of the cisternae
References

1. Assan, R., Hautecouverture, G., Guillemant, S., Dauchy, F., Protin, P., Dérot, M.: Evolution de paramètres hormonaux (glucagon, cortisol, hormone somatotrop) et énergétiques (glucose, acides gras, gly cérol libre) dans dix acido-cétoses diabétiques graves traitées. Path. Biol. (Paris) 17 1095-1105 (1969).

2. - Rosselin, G., Dolais, J.: Effets sur la glucagonémie des perfusions et ingestions d'acides aminés. Journ. Ann. Diabétologie, Hôtel-Dieu, pp. 25-41. Paris : Editions Flammarion 1967.

3. Boquist, L.: The endocrine pancreas of the Chinese hamster, Thesis. Umea: Tryckeriaktiebolaget 1969.

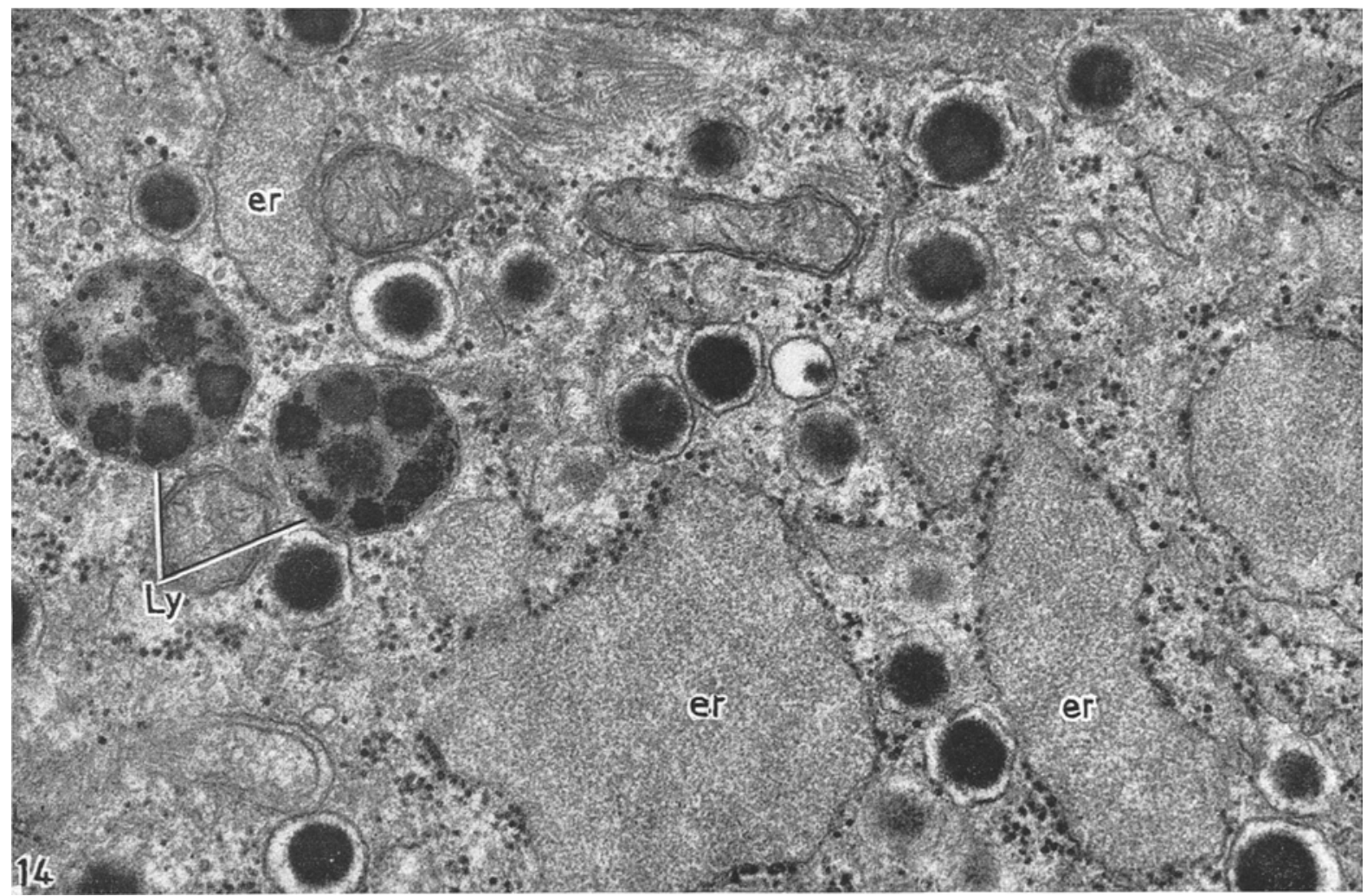

Fig. 14. Same animal as Fig. 12. In an A-cell, two multigranulated lytic bodies (Ly) and dilated cisternae of RER (er) are shown $(42800 \times)$

of the RER may occasionally be observed in the same cells, the authors are of the opinion that final judgment concerning the mechanism(s) responsible for the initiation of granulolysis is still to be deferred. As of the present they favour the view that $\alpha$-granulolysis might result not only from a response of A-cells to hyperglycemia, but also from that to other regulatory mechanisms, among which the concentration of circulating glucagon might be prominent. Indeed, presently available data appear to suggest that differential stimulatory and inhibitory signals may exist for glucagon synthesis, glucagon release and the initiation of granulolysis, and that they may independently affect any one of these three processes.
4. Buchanan, K.D., Vance, J.E., Dinstl, K., Williams R.H.: Effect of blood glucose on glucagon secretion in anesthetized dogs. Diabetes 18, 11-18 (1969).

5. Creutzfeldt, W., Creutzfeldt, C., Frerichs, H., Perings, E., Sickinger, K.: The morphological substrate of the inhibition of insulin secretion by diazoxide. Horm. Metab. Res. 1, 53-64 (1969).

6. Dupré, J., Curtis, J.D., Unger, R.H., Waddel, R.W., Beck, J.C.: Effects of secretin, pancreozymin or gastrin on the response of the endocrine pancreas to administration of glucose or arginine in man. J. clin. Invest. 48, 745-757 (1969).

7. - Rojas, L., White, J.J., Unger, R.H., Beck, C.J.: Effects of secretin on insulin and glucagon in portal and peripheral blood in man. Lancet 1966 II, 26.

8. Farquhar, M.: Lysosome function in regulating secretion: disposal of secretory granules in cells of the 
anterior pituitary gland. In: Lysosomes in biology and pathology. 2. Dingle, J.T., Fell, H. B. (Eds.). Amsterdam, London: North-Holland Inc. 1969.

9. Forssmann, W.G., Orci, L.: Ultrastructure and secretory cycle of the gastrin-producing cell. $Z$. Zellforsch. 101, 419-432 (1969)

10. Gerritsen, G.C., Dulin, W.F.: Characterization of diabetes in the chinese hamster. Diabetologia $\mathbf{3}, 74-$ 84 (1967)

11. Karnovsky, M.J.: Simple methods for "staining with lead" at high $\mathrm{pH}$ in electron microscopy. J. biophys. biochem. Cytol. 11, 729-732 (1961).

12. Luft, J.H.: Improvement in Epoxy-resin embedding methods. J. biophys. biochem. Cytol. 9, 409-414 (1961).

13. Luse, S.A., Caramia, F., Gerritsen, G., Dulin, W.E.: Spontaneous diabetes mellitus in the chinese hamster: an electron microscopic study of the islets of Langerhans. Diabetologia 3, 97-108 (1967).

14. Malaisse, W., Malaisse-Lagae, F., Gerritsen, G., Dulin, W.E., Wright, P.H.: Insulin secretion in vitro by the pancreas of the chinese hamster. Diabetologia $\mathbf{3}$, $109-114,(1967)$

15. Meier, H., Yerganian, G.A.: Spontaneous hereditary diabetes mellitus in chinese hamster (Cricetulus griseus): I. Pathological findings. Proc. Soc. exp. Biol. Med. 100, 810-815 (1959).

16. Morlini, D., Caramia, F.: Modificazioni ultrastrutturali delle isole pancreatiche nel diabete spontaneo dell' hamster cinese (Cricetulus griseus). 10th Congr. Soc. Ital. Path. 1967, p. 1-12.

17. Millonig, G.: Advantages of a phosphate buffer for 0s04 solutions in fixation. J. appl. Physiol. 32, 16371640 (1961).

18. Ohneda, A., Aguilar-Parada, E., Eisentraut, A.M., Unger, R.H.: Control of pancreatic glucagon secre. tion by glucose. Diabetes 18, 1-10 (1969)

19. - - - - : Characterization of response of circulating glucagon to intraduodenal and intravenous administration of amino acid. J. clin. Invest. 47, 23052322 (1968).

20. Orci, L., Renold, A.E., Rouiller, Ch.: Intracellular granulolysis in A-cells of diabetic animals. In: Meta- bolism and structure of pancreatic islets. Falkmer, S. Hellman, B., Täljedal, I.-B. (Eds.). Oxford: Pergamon Press (in press) 1970.

21. - Junod, A., Pietet, R., Renold, A.E., Rouiller, Ch.: Granulolysis in A-cells of endocrine pancreas in spontaneous and experimental diabetes in animals. J. Cell Biol. 38, $462-466$ (1968).

22. Renold, A.E., Zahnd, G.R., Christophe, J.: Diseussion on diabetes in chinese hamsters. In: Ciba Foundation Colloquia on Endocrinology Vol. 15: Diabetes mellitus, p. $42-44$. Cameron, M.P., O’Connor, M. (Eds.) London: J.A. Churchill 1964.

23. Smith, R.E., Farquhar, M.G.: Lysosome function in the regulation of the secretory process in cells of the anterior pituitary gland. J. Cell Biol. 31, 319-347 (1966).

24. Stauffacher, W., Orci, L., Amherdt, M., Burr, I.M., Balant, L., Froesch, E. R., Renold, A. E.: Metabolic state, pancreatic insulin content and B-cell morphology of normoglycemic spiny mice (Acomys cahirinus): Indications for an impairment of insulin secretion. Diabetologia (in press).

25. Unger, R.H., Eisentraut, A.M.: Studies of the physiologic role of glucagon. Diabetes 13, 563-568 (1964).

26. - Ketterer, H., Dupré, J., Eisentraut, A.M.: The effects of secretin, pancreozymin and gastrin on insulin and glucagon secretion in anesthetized dogs. J. clin. Invest. 46, 630 (1967).

27. - Ohneda, A., Aguilar-Parada, E., Eisentraut, A.M. The role of aminogenic glucagon secretion in blood glucose homeostasis. J. clin. Invest. 48, 810-822 (1969).

28. - - Valverde, I., Eisentraut, A.M., Exton, J.: Characterization of the response of circulating gluca gon-like immunoreactivity to intraduodenal and intravenous administration of glucose. J. clin. Invest. 47, $48-65(1968)$.

Dr. L. Orei

Institute of Histology

and Embryology

University of Geneva

CH 1211 Geneva 